The Power of Religious Societies

in Shaping Early Modern Society and Identities 


\section{Crossing Boundaries}

\section{Turku Medieval and Early Modern Studies}

The series from the Turku Centre for Medieval and Early Modern Studies (TUCEMEMS) publishes monographs and collective volumes placed at the intersection of disciplinary boundaries, introducing fresh connections between established fields of study. The series especially welcomes research combining or juxtaposing different kinds of primary sources and new methodological solutions to deal with problems presented by them. Encouraged themes and approaches include, but are not limited to, identity formation in medieval/early modern communities, and the analysis of texts and other cultural products as a communicative process comprising shared symbols and meanings.

\section{Series Editor}

Matti Peikola, University of Turku, Finland

\section{Editorial Board}

Matti Peikola, Department of Modern Languages, University of Turku (Editorin-chief)

Janne Harjula, Adjunct Professor of Historical Archaeology, University of Turku Johanna Ilmakunnas, Acting Professor of Finnish History, School of History, Culture and Arts Studies, University of Turku

Hemmo Laiho, Postdoctoral Researchers, Department of Philosophy, University of Turku

Satu Lidman, Adjunct Professor of History of Criminal law, Faculty of Law/Legal History, University of Turku

Aino Mäkikalli, Postdoctoral Researcher, Department of Comparative Literature, University of Turku

Kirsi-Maria Nummila, Adjunct Professor of Finnish language, University of Turku; University Lecturer of Finnish, University of Helsinki.

Kirsi Salonen, Associate Professor, School of History, Culture and Arts Studies, University of Turku 


\section{The Power of Religious Societies in Shaping Early Modern Society and Identities}

Rose-Marie Peake 
Cover illustration: Courtesy of AP-HP / F. Marin. This work is kept at the Musée de l'Assistance Publique - Hôpitaux de Paris.

Cover design: Coördesign, Leiden

Lay-out: Crius Group, Hulshout

$\begin{array}{ll}\text { ISBN } & 9789462986688 \\ \text { e-ISBN } & 978 \text { 90 } 48537976 \\ \text { DOI } & 10.5117 / 9789462986688 \\ \text { NUR } & 685\end{array}$

(c) Rose-Marie Peake / Amsterdam University Press B.V., Amsterdam 2020

All rights reserved. Without limiting the rights under copyright reserved above, no part of this book may be reproduced, stored in or introduced into a retrieval system, or transmitted, in any form or by any means (electronic, mechanical, photocopying, recording or otherwise) without the written permission of both the copyright owner and the author of the book. 